\title{
Effect of sterilization and of dietary fat and carbohydrate content on food intake, activity level, and blood satiety-related hormones in female $\operatorname{dogs}^{1}$
}

\author{
S. Schauf, $*$ A. Salas-Mani, $\uparrow$ C. Torre,$\uparrow$ G. Bosch, $\$$ H. Swarts, $\S$ and C. Castrillo ${ }^{* 2}$ \\ *Departamento de Producción Animal y Ciencia de los Alimentos, Universidad de Zaragoza, \\ Miguel Servet 177, 50013 Zaragoza, Spain; †Affinity Petcare, Research and Development Department, \\ 08174 Barcelona, Spain; and \$Animal Nutrition Group and §Human and Animal Physiology Group, \\ Department of Animal Sciences, Wageningen University, PO Box 338, 6700, Wageningen, the Netherlands
}

\begin{abstract}
Animal sterilization is suggested to promote food overconsumption, although it is unknown whether this effect is mediated by variations in satiety-related hormones, which are released in response to food intake. The aim of this study was to evaluate the effect of sterilization and of the main energy-delivery nutrients, fat and nonstructural carbohydrates, on food intake, blood concentration of satiety-related hormones, and activity level in dogs. In a 2-phase experiment (phase I [Ph.I], $74 \mathrm{~d}$, and Ph.II, $84 \mathrm{~d}$ ), 12 female Beagle dogs were assigned to a control group (intact in both phases) and a sterilization group (spayed $20 \mathrm{~d}$ before $\mathrm{Ph}$.II). In each phase, dogs received a high-carbohydrate (HC) diet (313 and $105 \mathrm{~g} / \mathrm{kg}$ DM starch and fat, respectively) and a highfat (HF) diet (191 and $213 \mathrm{~g} / \mathrm{kg} \mathrm{DM}$ starch and fat, respectively), both high in total dietary fiber $(>200 \mathrm{~g} /$ $\mathrm{kg} \mathrm{DM}$ ) and providing $27 \% \mathrm{ME}$ as protein, in 2 consecutive periods following a crossover arrangement. During each period, dogs' voluntary DMI and activity level were recorded during $5 \mathrm{~d}$. Then, energy allowance was restricted to 0.7 maintenance and the level of intake of a common challenge food offered $4 \mathrm{~h}$ after feeding the experimental diets (challenge food intake
\end{abstract}

[ChFI]) was used as an index of the satiety state of dogs. Blood concentration of active ghrelin, cholecystokinin (CCK), total peptide YY (PYY), and insulin were determined before and 15, 60, 120, 240, and 360 min after feeding. Voluntary DMI was greater $(P<$ 0.05) in HF-fed dogs, but ChFI did not differ between diets $(P>0.10)$. Dogs fed the HF diet showed a lower increase of CCK at $120(P<0.01)$ and $240 \mathrm{~min}(P<$ $0.05)$, resulting in a lower $(P<0.001)$ total area under the curve from 0 to 240 min $\left(\right.$ tAUC $\left._{0-240}\right)$. A lower PYY elevation $(P<0.05)$ was also found in HF-fed dogs at $120 \mathrm{~min}$. Only active ghrelin concentration at 240 min and insulin tAUC ${ }_{0-240}$ correlated $(P<0.05)$ with ChFI ( $\mathrm{r}=0.357$ and $\mathrm{r}=-0.364$, respectively), suggesting a role of these hormones in appetite. Dog sterilization did not affect voluntary DMI, ChFI, or blood hormones $(P>0.10)$ but led to a reduced activity level compared with control dogs $(P<0.05)$. In summary, dog sterilization was not associated with an impaired appetite control. Feeding dogs the HF diet led to energy overconsumption and to a lower blood elevation of CCK and PYY but was not associated with a weaker satiating effect $4 \mathrm{~h}$ later compared with the $\mathrm{HC}$ diet.

Key words: activity, dietary fat and carbohydrates, dog sterilization, food intake, satiety hormones.

\section{(C) 2016 American Society of Animal Science. All rights reserved.}

\footnotetext{
${ }^{1}$ This study was financially supported by Affinity Petcare (project number 2010-0454). A. Salas-Mani and C. Torre are employees of Affinity-Petcare. All of the authors read and approved the final manuscript. The authors express their gratitude to Llorenç Badiella, from the Servei d'Estadística Aplicada, Universitat Autònoma of Barcelona, for his support in the statistical analysis of data and Jens F. Rehfeld for conducting the cholecystokinin analysis.

${ }^{2}$ Corresponding author: ccastri@unizar.es

Received November 17, 2015.

Accepted March 19, 2016.
}

J. Anim. Sci. 2016.94:4239-4250
doi:10.2527/jas2015-0109

\section{INTRODUCTION}

Food intake control involves the secretion of gutderived hormones, which exert an orexigenic (ghrelin) or anorexigenic (i.e., cholecystokinin $[\mathbf{C C K}]$, total peptide YY [PYY], and insulin) action in a meal-tomeal context (Hameed et al., 2009), with the response differing between dietary macronutrients (Karhunen 
et al., 2008). Conflicting results exist regarding carbohydrates and fat, with a series of human studies reporting a weaker effect of fat on satiety (Blundell et al., 1993; Lawton et al., 1993), whereas in dogs, Geoghegan et al. (1997) found a larger suppression of sham feeding following an intraduodenal infusion of oleate compared with an intraduodenal infusion of dextrose. Carbohydrates are regarded most effective in suppressing ghrelin and in increasing insulin after a meal in humans, whereas fat is found to elicit a major increase of CCK and PYY (Karhunen et al., 2008). Available data in dogs is limited, with Greeley et al. (1989) reporting a major increase of PYY after intraduodenal fat and Lubbs et al. (2010) reporting a similar ghrelin response after oral loads of fat and carbohydrates, and a relationship between blood hormone variations and food intake is not consistently established (Bosch et al., 2009). On the other hand, there is evidence that estradiol attenuates the orexigenic effect of ghrelin (Clegg et al., 2007) and enhances the satiating potency of CCK (Butera et al., 1993) and PYY (Papadimitriou et al., 2007). Accordingly, an increase of food intake has been reported in dogs after sterilization (Houpt et al., 1979; Jeusette et al., 2004), although hitherto, its effect on gut hormones remains undetermined. The objective of this study was to evaluate the effect of feeding highcarbohydrate or high-fat diets on food intake and blood concentration of gut-derived hormones in dogs before and after sterilization. We hypothesized that dog sterilization would result in food overconsumption via variations in gut hormones and that this response would be differentially evoked by fat and carbohydrates.

\section{MATERIALS AND METHODS}

Animal housing and experimental procedures were approved by the Ethic Committee for Animal Experimentation of the University of Zaragoza (PI26/13).

\section{Animals and Diets}

Twelve intact female Beagle dogs aged between 2 and $6 \mathrm{yr}$ with a mean BW of $13.6 \pm 0.6 \mathrm{~kg}$ and BCS of $5.3 \pm 0.3$ on a 9-point scale (optimal 5/9; Laflamme, 1997) were randomly assigned to a sterilization group (SG; $n=6)$ and a control group (CG; $n=6)$ according to their BW and age. The dogs were individually housed in indoor concrete floor kennels ( 2.0 by $2.5 \mathrm{~m})$ with free access to outdoor courts ( 2.0 by $5.0 \mathrm{~m})$. Indoor temperature was maintained between 18 and $24^{\circ} \mathrm{C}$ throughout the experiment and drinking water was provided ad libitum. Two dry extruded diets were formulated to meet the Association of American Feed Control Officials (AAFCO, 2011) nutritional recommendations. Under
Table 1. Ingredient and chemical composition of the experimental diets

\begin{tabular}{|c|c|c|}
\hline \multirow[b]{2}{*}{ Item } & \multicolumn{2}{|c|}{ Diets $^{1}$} \\
\hline & $\mathrm{HC}$ & $\mathrm{HF}$ \\
\hline \multicolumn{3}{|l|}{ Ingredient composition, $\mathrm{g} / \mathrm{kg}$, as-fed basis } \\
\hline Corn & 254.4 & 20.0 \\
\hline Poultry byproduct meal ( $63 \% \mathrm{CP}$ and $17 \%$ ash) & 202.8 & 204.1 \\
\hline Corn gluten meal $(60 \% \mathrm{CP})$ & 79.9 & 136.4 \\
\hline Lard & 24.4 & 123.0 \\
\hline Rice & 93.9 & 95.4 \\
\hline Barley & 75.1 & 95.4 \\
\hline Soybean meal ( $48 \% \mathrm{CP})$ & 45.1 & 95.4 \\
\hline Pea fiber & 56.3 & 57.2 \\
\hline Hydrolyzed pork liver & 50.7 & 51.5 \\
\hline Cellulose & 40.4 & 41.0 \\
\hline Beet pulp & 37.6 & 38.1 \\
\hline Vitamin-mineral premix ${ }^{2}$ & 31.0 & 33.0 \\
\hline Gum arabic & 4.7 & 4.8 \\
\hline Guar gum & 4.7 & 4.8 \\
\hline \multicolumn{3}{|l|}{ Analyzed chemical composition, $\mathrm{g} / \mathrm{kg}$ DM } \\
\hline Ash & 77.5 & 78.7 \\
\hline $\mathrm{CP}$ & 269.0 & 307.0 \\
\hline Ether extract & 105.0 & 213.0 \\
\hline Crude fiber & 82.7 & 78.9 \\
\hline Nitrogen-free extractives ${ }^{3}$ & 465.8 & 322.4 \\
\hline Starch & 313.0 & 191.0 \\
\hline Total dietary fiber & 226.0 & 211.0 \\
\hline Insoluble dietary fiber & 198.0 & 174.0 \\
\hline Soluble dietary fiber & 28.2 & 37.3 \\
\hline \multicolumn{3}{|l|}{ Energy content, $\mathrm{MJ} / \mathrm{kg} \mathrm{DM}$} \\
\hline $\mathrm{GE}^{4}$ & 20.0 & 22.8 \\
\hline $\mathrm{ME}^{5}$ & 14.8 & 16.9 \\
\hline
\end{tabular}

${ }^{1} \mathrm{HC}=$ high-carbohydrate; $\mathrm{HF}=$ high-fat.

${ }^{2}$ Supplying, per kilogram diet, $3.19 \mathrm{~g} \mathrm{Na}, 5.96 \mathrm{~g} \mathrm{Cl}, 1.77 \mathrm{~g} \mathrm{~K}, 0.280 \mathrm{~g}$ $\mathrm{Mg}, 200 \mathrm{mg} \mathrm{Fe}, 7.14 \mathrm{mg} \mathrm{Cu}, 198 \mathrm{mg} \mathrm{Zn}, 50.5 \mathrm{mg} \mathrm{Mn}, 0.23 \mathrm{mg} \mathrm{Se}, 0.146$ $\mathrm{mg}$ Co, $7.29 \mathrm{mg}$ vitamin $\mathrm{A}, 0.040 \mathrm{mg}$ vitamin $\mathrm{D}_{3}, 446 \mathrm{mg}$ vitamin $\mathrm{E}, 0.410$ $\mathrm{mg}$ vitamin $\mathrm{K}_{3}, 41.4 \mathrm{mg}$ vitamin $\mathrm{B}_{1}, 20.2 \mathrm{mg}$ vitamin $\mathrm{B}_{2}, 150 \mathrm{mg}$ vitamin $\mathrm{B}_{3}, 38.2 \mathrm{mg}$ vitamin $\mathrm{B}_{5}, 10.6 \mathrm{mg}$ vitamin $\mathrm{B}_{6}, 0.080 \mathrm{mg}$ vitamin $\mathrm{B}_{7}, 5.07$ $\mathrm{mg}$ vitamin $\mathrm{B}_{9}, 0.120 \mathrm{mg}$ vitamin $\mathrm{B}_{1} 2$ and $315 \mathrm{mg}$ vitamin $\mathrm{C}$.

${ }^{3}$ Calculated by subtracting the ash, $\mathrm{CP}$, ether extract, and crude fiber contents from the DM.

${ }^{4}$ Determined by calorimetric bomb.

${ }^{5}$ Estimated as GE $\times$ GE digestibility coefficient $(91.2-[1.43 \times \%$ crude fiber]/100) and assuming urinary energy losses of $4.35 \mathrm{~kJ} / \mathrm{g} \mathrm{CP}$ (NRC, 2006).

these premises, a diet high in potentially digestible carbohydrates, in terms of nitrogen-free extractives (NFE), and low in fat (high carbohydrate [HC]) and a diet high in fat and low in NFE (high fat [HF]), both with a high content in total dietary fiber $(>200 \mathrm{~g} / \mathrm{kg} \mathrm{DM})$, were formulated. Both diets had a similar CP content on a ME basis (approximately 27\%) to procure a similar level of protein intake in $\mathrm{g} / \mathrm{kg} \mathrm{BW} \mathrm{B}^{0.75}$ when offered at the same level of intake (in $\mathrm{kJ} / \mathrm{kg} \mathrm{BW}^{0.75}$ ). Ingredient and chemical composition of the experimental diets is shown in Table 1. The ME content of both diets was estimated using the NRC (2006) approach as the product of deter- 
A

\begin{tabular}{|c|c|c|c|c|c|}
\hline \multirow{2}{*}{$\begin{array}{c}\text { Feeding } \\
\text { level }\end{array}$} & \multicolumn{2}{|r|}{ Ad libitum } & \multirow[t]{2}{*}{ MER } & \multicolumn{2}{|c|}{ 0.7 MER } \\
\hline & Adaptation & $\begin{array}{c}\text { DMI } \\
+ \\
\text { Activity } \\
\text { recording } \\
\end{array}$ & & Challenge food intake & $\begin{array}{c}\text { Blood } \\
\text { sampling }\end{array}$ \\
\hline Days & 0 to 9 & 10 to 14 & 15 to 19 & \begin{tabular}{l|l|l|l|}
22 & 25 & 28 & 31
\end{tabular} & 35 to 37 \\
\hline
\end{tabular}

B

\begin{tabular}{|c|c|c|c|c|c|c|}
\hline \multirow{2}{*}{$\begin{array}{c}\text { Feeding } \\
\text { level }\end{array}$} & MER & \multirow{2}{*}{$\begin{array}{c}\text { d libitum } \\
\text { DMI } \\
+ \\
\text { Activity } \\
\text { recording }\end{array}$} & \multicolumn{2}{|c|}{ MER } & \multicolumn{2}{|c|}{0.7 MER } \\
\hline & Adaptation & & & $\begin{array}{l}\text { Digestibility } \\
\text { trial }\end{array}$ & Challenge food intake & $\begin{array}{l}\text { Blood } \\
\text { sampling }\end{array}$ \\
\hline Days & 0 to 9 & 10 to 14 & 15 to 19 & 20 to 24 & 27 & 40 to 42 \\
\hline
\end{tabular}

Figure 1. Experimental procedures followed in each of the 2 crossover periods of phase I (A) and phase II (B) of the study. In each figure, the timing of BW record (*), voluntary DMI, activity recording, challenge food intake, digestibility trial, and blood sampling is shown. MER = maintenance energy requirements.

mined GE multiplied by the apparent GE digestibility coefficient (GE digestibility $=[91.2-(1.43 \times \%$ crude fiber, in DM)/100]) and assuming urinary energy losses of $4.35 \mathrm{~kJ} / \mathrm{g}$ CP. This estimated ME content was used to adjust the level of intake throughout experiment.

\section{Experimental Design and Procedures}

The study lasted 6 mo and comprised 2 phases (phase I [Ph.I] and phase II [Ph.II]). In each phase, all of the dogs were fed the HC and HF diets in 2 consecutive periods following a crossover arrangement. The time schedule of procedures followed in each of the 2 periods of Ph.I and Ph.II is shown in Fig. 1A and 1B, respectively. Phase I started at the beginning of the summer and lasted $74 \mathrm{~d}$ (37 d/period), during which all of the dogs were intact. Afterward, dogs of the SG were spayed in the Veterinary Hospital of the University of Zaragoza (Zaragoza, Spain), and, after a 20-d recovery period, $\mathrm{Ph}$.II was conducted for $84 \mathrm{~d}$ ( $42 \mathrm{~d} /$ period). Each period in $\mathrm{Ph}$.I consisted of $5 \mathrm{~d}$ of adaptation to the diets, which were individually fed at $0900 \mathrm{~h}$ to meet the estimated maintenance energy requirements (MER) for laboratory Beagle dogs (552 kJ ME/kg optimal $\mathrm{BW}^{0.75} \mathrm{~d}$; NRC, 2006). The optimal BW of dogs was estimated at the beginning of the study by increasing or reducing the starting BW $10 \%$ per unit of BCS below or above 5 (German et al., 2009). Food allowance was gradually increased in the following $4 \mathrm{~d}$ until food refusals were ensured, and from 10 to $14 \mathrm{~d}$ food refusals were collected daily, pooled on an individual basis, and dried to calculate the average daily voluntary DMI. Afterward, dogs were adapted to consume their daily food from 0900 to $0920 \mathrm{~h}$ at a level of intake close to MER for $5 \mathrm{~d}$ and at 0.7 MER for the next $18 \mathrm{~d}$. This level of energy restriction matches the estimated daily energy intake required for the maintenance of BW in spayed dogs (Jeusette et al., 2004). After $2 \mathrm{~d}$ at 0.7 MER, 4 satiety tests were conducted leaving $2 \mathrm{~d}$ in between consecutive tests. In each satiety test, dogs were offered a challenge food $240 \mathrm{~min}$ after consumption of the experimental diets. The amount of challenge food offered ( $600 \mathrm{~g}$, as-fed basis) was based on the level of food allowances that assured food refusals during ad libitum feeding. The challenge food was a commercial dry extruded diet (Brekkies Excel; Affinity Petcare, Barcelona, Spain) providing $230 \mathrm{~g} \mathrm{CP}, 140 \mathrm{~g}$ ether extract (EE), and $2.70 \mathrm{~g}$ crude fiber (CF) per kilogram food, on an as-fed basis, as specified in the label, with an estimated ME content of $14.9 \mathrm{MJ} / \mathrm{kg}$ fresh matter, by applying the Atwater factors $14.63,35.56$, and $14.64 \mathrm{~kJ}$ per gram of $\mathrm{CP}$, EE, and NFE, respectively. After $20 \mathrm{~min}$, food refusals were collected and the challenge food intake (ChFI) of each dog was recorded.

Physical activity was assessed using activity monitors (Actical Philips Respironics, Amsterdam, the Netherlands) attached to the collar of 5 dogs from each group (CG and SG) during ad libitum feeding. The device consisted of an omnidirectional accelerometer that compiled the intensity and duration of the movements and converted them into arbitrary numbers referred to as activity counts (Hansen et al., 2007). Accelerometer data epoch was set at $1 \mathrm{~min}$ and daily activity was expressed as average counts per minute. 
On the last $3 \mathrm{~d}$ of each period, blood samples were collected before meal distribution (time 0 ) and at 15, 60, 120,240 , and $360 \mathrm{~min}$ after consumption of the experimental diets at 0.7 MER ( 2 dogs per diet/d). The day before blood sampling, dogs were sedated using $0.20 \mathrm{mg} /$ kg BW of acepromazine (Calmo Neosan; Pfizer, Madrid, Spain) and $0.01 \mathrm{mg} / \mathrm{kg}$ of buprenorphine (Buprex; Schering-Plough, Madrid, Spain), and a venous catheter (BD Instye-W 18 G, $1.3 \times 45$ mm; Becton Dickinson, Madrid, Spain) was placed in the jugular vein. Catheter patency was maintained by flushing with $1 \mathrm{~mL}$ heparinized saline (10 IU of heparine $/ \mathrm{mL} 0.9 \% \mathrm{NaCl}$ solution) at the time of catheter placement and before and after blood sampling (approximately $0.5 \mathrm{~mL}$ ). Blood flushed with the heparinized solution was discarded before sampling.

Samples for active ghrelin, CCK, and PYY $(2 \mathrm{~mL}$ blood per hormone) were collected in chilled tubes containing $1.8 \mathrm{mg} \mathrm{K} 3$ EDTA per $1 \mathrm{~mL}$ blood (Aquisel, Barcelona, Spain). Tubes for CCK and PYY analyses contained $10 \mu \mathrm{L} / \mathrm{mL}$ blood of an aprotinin solution (10 mg aprotinin bovine [Sigma-Aldrich Chemie $\mathrm{GmbH}$, Steinhelm, Germany] dissolved in $1 \mathrm{~mL}$ of $0.9 \% \mathrm{NaCl}$ solution). After gently mixing, tubes were kept on ice until centrifugation (within $30 \mathrm{~min}$ after blood collection). For insulin analysis, $2 \mathrm{~mL}$ of blood were collected in serum separator tubes (BD Vacutainer; Beckton Dickinson, Plymouth, UK) and allowed to clot at room temperature. All tubes were centrifuged at $2,000 \times g$ for $10 \mathrm{~min}$ at $4^{\circ} \mathrm{C}$. For active ghrelin analysis, plasma samples were transferred to safe-lock tubes (Eppendorf, Hamburg, Germany) containing $10 \mu \mathrm{L}$ of a phenylmethylsulfonyl fluoride solution (10 mg phenylmethylsulfonyl fluoride [Sigma-Aldrich Chemie $\mathrm{GmbH}$ ] dissolved in $1 \mathrm{~mL}$ $100 \%$ isopropanol) and $50 \mu \mathrm{L}$ of $\mathrm{HCl}(1 \mathrm{~N})$ per $1 \mathrm{~mL}$ of plasma. All samples were stored in cryovials at $-80^{\circ} \mathrm{C}$ until analyses.

In $\mathrm{Ph}$.II, both periods included $9 \mathrm{~d}$ more between ad libitum feeding and the satiety tests, during which the apparent digestibility of the experimental diets was determined in both spayed and intact dogs. Briefly, dogs were fed the experimental diets at a level of intake close to the MER for $5 \mathrm{~d}$ and then food intake and feces were recorded daily during the next $5 \mathrm{~d}$. Feces from each dog were collected directly from the kennel floor twice a day, dried at $65^{\circ} \mathrm{C}$ for $48 \mathrm{~h}$, pooled per dog at the end of the collection period, and stored until analyses. Dogs were weighed at the beginning and at the end of each experimental period in $\mathrm{Ph}$.I and Ph.II.

\section{Analytical Methods}

Samples of the HC and HF diets were collected weekly and pooled per phase. Food and dried fecal samples were milled to pass a 1-mm screen and ana- lyzed for DM and ash contents by drying to a constant weight at $105^{\circ} \mathrm{C}$ and combustion at $550^{\circ} \mathrm{C}$ for $6 \mathrm{~h}$, respectively. Analyses of food and fecal CP, EE, and CF were performed according to AOAC (2005) procedures (methods 976.05, 954.02, and 978.10, respectively). The NFE content of the diets was calculated by subtracting the ash, CP, EE, and CF from the DM. The total dietary fiber content of foods was calculated as the sum of soluble and insoluble dietary fiber, according to methods 993.19 and 991.42 , respectively, outlined by the AOAC (1995). The starch content of the diets was enzymatically analyzed (K-TSTA kit; Megazyme International, Wicklow, Ireland). D-Glucose and maltodextrins were previously washed with $80 \%$ ethanol and resistant starch was predissolved by stirring the sample with $2 \mathrm{M} \mathrm{KOH}$ at $4^{\circ} \mathrm{C}$. The GE content of food and feces was determined in an adiabatic bomb calorimeter (IKA C-4000; Janke-Kunkel, Staufen, Germany). The ME content of the diets was calculated by subtracting $5.23 \mathrm{~kJ} / \mathrm{g}$ digestible CP from their DE (NRC, 2006). Commercial RIA kits from Linco Research (Billerica, MA; $100 \%$ cross-reactivity with canine ghrelin, PYY, and insulin), previously applied in dogs (Bosch et al., 2009; Zietlow et al., 2010), were used for the determination of blood insulin (human-specific insulin RIA with a detection limit of 2.715 microunits $/ \mathrm{mL}$ and intraassay and interassay CV of 3.3 and $4.5 \%$, respectively), total PYY (rat-mouse PYY RIA with a detection limit of $78.1 \mathrm{pg} / \mathrm{mL}$ and intra-assay and interassay CV of 3.6 and $8.5 \%$, respectively), and active ghrelin (Ghrelin active RIA, with a detection limit of $7.8 \mathrm{pg} / \mathrm{mL}$ and intraassay and interassay CV of 7.4 and $13.5 \%$, respectively). Plasma CCK was determined using a RIA procedure developed to bind to different bioactive forms of CCK in mammals (CCK-8, CCK-22, CCK-33, and CCK-58). The detection limit was $0.1 \mathrm{p} M$ and the intra-assay and interassay CV ranged from 4 to $15 \%$ (Rehfeld, 1998).

\section{Calculations and Statistical Analyses}

All data were analyzed using the Statistical Analysis Systems software package version 9.2 (SAS Inst. Inc., Cary, NC). For active ghrelin, CCK, PYY, and insulin, the sum of the net (baseline subtracted) area under the curve (AUC) from 0 to $120 \mathrm{~min}\left(\mathbf{n} \mathbf{A U C} \mathbf{C}_{\mathbf{0}-\mathbf{1 2 0}}\right)$ and from 120 to $360 \min \left(\mathbf{n A U C} \mathbf{~}_{\mathbf{1 2 0}-\mathbf{3 6 0}}\right.$ ) and the net and total

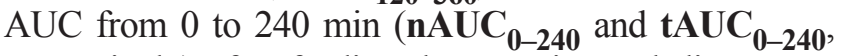
respectively) after feeding the experimental diets were approximated using the trapezoidal summation method ( $\sum$ area $=\sum h_{\mathrm{i}} \times b_{\mathrm{i}}$, in which $h \mathrm{i}$ is the mean score of pairs of adjacent time points and $b \mathrm{i}$ is the time interval between these points) and weighted by time. In Ph.II, the effects of diet and of sterilization (group effect) on nutrient and GE digestibility were analyzed using the mixed 
Table 2. Effect of diet and sterilization (group effect) on nutrient and energy apparent digestibility coefficients and on the energy content of the experimental diets ${ }^{1}$

\begin{tabular}{|c|c|c|c|c|c|c|c|c|}
\hline \multirow[b]{2}{*}{ Item } & \multicolumn{2}{|c|}{ Diet $^{2}$} & \multicolumn{2}{|c|}{ Group $^{3}$} & \multirow[b]{2}{*}{$\mathrm{SED}^{4}$} & \multirow[b]{2}{*}{$\mathrm{SED}^{5}$} & \multicolumn{2}{|c|}{$P$-value ${ }^{6}$} \\
\hline & $\mathrm{HC}$ & $\mathrm{HF}$ & $\mathrm{CG}$ & SG & & & Diet & Group \\
\hline \multicolumn{9}{|l|}{ Digestibility } \\
\hline $\mathrm{DM}$ & 0.726 & 0.740 & 0.731 & 0.735 & 0.007 & 0.013 & 0.087 & 0.744 \\
\hline OM & 0.754 & 0.767 & 0.758 & 0.763 & 0.006 & 0.012 & 0.070 & 0.728 \\
\hline $\mathrm{CP}$ & 0.814 & 0.841 & 0.827 & 0.828 & 0.006 & 0.007 & 0.002 & 0.892 \\
\hline Ether extract & 0.857 & 0.921 & 0.888 & 0.891 & 0.004 & 0.010 & $<0.001$ & 0.734 \\
\hline Crude fiber & 0.182 & 0.125 & 0.119 & 0.186 & 0.042 & 0.044 & 0.212 & 0.159 \\
\hline GE & 0.764 & 0.803 & 0.781 & 0.786 & 0.006 & 0.018 & $<0.001$ & 0.355 \\
\hline \multicolumn{9}{|l|}{ Energy content } \\
\hline $\mathrm{DE}, \mathrm{MJ} / \mathrm{kg} \mathrm{DM}$ & 15.3 & 18.3 & 16.7 & 16.8 & 0.1 & 0.2 & $<0.001$ & 0.355 \\
\hline $\mathrm{ME},{ }^{7} \mathrm{MJ} / \mathrm{kg} \mathrm{DM}$ & 14.2 & 16.9 & 15.5 & 15.6 & 0.1 & 0.2 & $<0.001$ & 0.358 \\
\hline \multicolumn{9}{|c|}{${ }^{1}$ Values are least squares means for each diet $(n=12)$ and each animal group $(n=12)$. } \\
\hline \multicolumn{9}{|c|}{${ }^{2} \mathrm{HC}=$ high-carbohydrate; $\mathrm{HF}=$ high-fat. } \\
\hline \multicolumn{9}{|c|}{${ }^{3} \mathrm{CG}=$ control group; $\mathrm{SG}=$ sterilization group. Denotes differences between sexually intact dogs of the CG and spayed dogs of the $\mathrm{SG}$. } \\
\hline \multicolumn{9}{|c|}{${ }^{4} \mathrm{SE}$ of the difference (SED) for comparisons between diets. } \\
\hline \multicolumn{9}{|c|}{${ }^{5} \mathrm{SED}$ for comparisons between CG and SG. } \\
\hline \multicolumn{9}{|c|}{${ }^{6}$ The interaction diet $\times$ group was not significant $(P>0.10)$ for any of the parameters. } \\
\hline${ }^{7}$ Estimated by sub & g $5.23 \mathrm{~kJ}$ & tible CP & DE con & & & & & \\
\hline
\end{tabular}

procedure (PROC MIXED) including in the model the effects of diet, group, and the interaction (diet $\times$ group) as fixed effects and period and animal as random effects. Voluntary DMI (average of $5 \mathrm{~d}$ ), ChFI (average of the 4 satiety tests), and activity level (average of the $5 \mathrm{~d}$ of ad libitum food intake recording) along with the basal concentration and the net and total AUC of blood hormones were analyzed including the fixed effect of phase and the interactions diet $\times$ phase, group $\times$ phase, and diet $\times$ group $\times$ phase in the model. According to the experimental design, the effect of sterilization is given by the interaction group $\times$ phase, denoting whether changes in the SG dogs from $\mathrm{Ph}$.I to $\mathrm{Ph}$.II differed from dogs in the CG. The time course of postprandial variation of blood hormones was analyzed including the sampling time after feeding (time $=15,60,120,240$, and $360 \mathrm{~min}$ ) in the model as repeated measures subjected to animal by period by phase within group. Pairwise means comparisons were made using the Tukey's test. Correlations between ChFI and $\mathrm{nAUC}_{0-240}$, tAUC $_{0-240}$, and the concentration of blood hormones at 240 min after feeding the experimental diets were calculated using the PROC CORR statement. Level of significance was set at $P<0.05$, and $0.05 \leq P<0.10$ was considered a trend. The results in the text are expressed as means \pm SEM. In tables, the SE of the difference for comparisons between diets and between phases within the $C G$ and the $S G$ is provided.

\section{RESULTS}

All dogs remained healthy throughout the study. During Ph.I, the initial and final BW of SG dogs (still in- tact) was, in both measurements, $13.3 \pm 0.6 \mathrm{~kg}$ and varied from $13.9 \pm 0.5$ to $13.8 \pm 0.6 \mathrm{~kg}(P>0.10)$ in $\mathrm{CG}$ dogs. During Ph.II, dogs' BW varied from $13.7 \pm 0.6$ to $13.9 \pm$ $0.7 \mathrm{~kg}(P>0.10)$ in spayed dogs of the SG and from 14.2 \pm 0.6 to $14.1 \pm 0.5 \mathrm{~kg}(P>0.10)$ in intact dogs of the CG.

Dogs fed the HF diet showed a greater apparent digestibility of EE $(P<0.001), \mathrm{CP}(P<0.01)$, and GE $(P<0.001)$ than HC-fed dogs (Table 2$)$. The DE and ME contents were also greater $(P<0.001)$ for the HF diet. Sterilization did not affect nutrient and energy digestibility, regardless of the composition of the diet (group and diet $\times$ group, $P>0.10$ ).

\section{Voluntary Food Intake, Challenge Food Intake, and Activity Level}

Food intake and activity data are summarized in Table 3. Ad libitum distribution of the HF diet resulted in a greater voluntary DMI $(P<0.05)$ and ME intake $(P<$ $0.001)$ compared with the HC diet. This diet effect was consistent between phases and was not affected by sterilization (diet $\times$ phase and diet $\times$ phase $\times$ group, $P>0.10$ ). However, no differences between diets were found in postprandial ChFI $(P>0.10)$. Voluntary DMI tended to increase $(P=0.056)$ from $\mathrm{Ph}$.I to Ph.II, with the increase being similar in CG and SG dogs (group $\times$ phase, $P>$ $0.10)$. There was an increase $(P<0.001)$ in $\mathrm{ChFI}$ from $\mathrm{Ph} . \mathrm{I}$ to $\mathrm{Ph} . \mathrm{II}$, and although the increase accounted for up to $33 \%$ in CG dogs and $56 \%$ in SG dogs, the interaction group $\times$ phase was not significant $(P>0.10)$.

Dogs' activity level during ad libitum feeding tended to be lower $(P=0.057)$ in dogs fed the HF diet 
Table 3. Effect of diet and sterilization on voluntary DMI and ME intake, on the level of intake of a challenge food offered $4 \mathrm{~h}$ after feeding the experimental diets (on an as-fed basis), and on dogs' activity level (unit counts/ min) during ad libitum feeding ${ }^{1}$

\begin{tabular}{|c|c|c|c|c|c|c|c|c|c|c|c|}
\hline \multirow[b]{3}{*}{ Item } & \multicolumn{2}{|c|}{$\operatorname{Diet}^{2}$} & \multicolumn{4}{|c|}{ Sterilization $^{3}$} & \multirow[b]{3}{*}{$\mathrm{SED}^{4}$} & \multirow[b]{3}{*}{$\mathrm{SED}^{5}$} & \multicolumn{3}{|c|}{$P$-value ${ }^{6}$} \\
\hline & \multirow[b]{2}{*}{$\mathrm{HC}$} & \multirow[b]{2}{*}{$\mathrm{HF}$} & \multicolumn{2}{|c|}{ CG } & \multicolumn{2}{|c|}{ SG } & & & & & Group \\
\hline & & & $\mathrm{Ph} . \mathrm{I}$ & $\mathrm{Ph} . \mathrm{II}$ & $\mathrm{Ph} . \mathrm{I}$ & Ph.II & & & Diet & Phase & $\times$ phase \\
\hline$\overline{\mathrm{DMI}}, \mathrm{g} / \mathrm{kg} \mathrm{BW} 0^{0.75}$ & 47.7 & 55.5 & 46.2 & 50.6 & 52.4 & 57.1 & 3.7 & 5.7 & 0.044 & 0.056 & 0.973 \\
\hline ME intake, $\mathrm{kJ} / \mathrm{kg} \mathrm{BW} \mathrm{W}^{0.75}$ & 671 & 940 & 719 & 795 & 817 & 887 & 61 & 86 & $<0.001$ & 0.057 & 0.960 \\
\hline $\mathrm{ChFI}^{7}{ }^{\mathrm{g}} / \mathrm{kg} \mathrm{BW}{ }^{0.75}$ & 44.2 & 41.2 & 35.0 & 46.6 & 34.8 & 54.4 & 2.7 & 3.8 & 0.279 & $<0.001$ & 0.147 \\
\hline Activity, counts/min & 211 & 188 & 147 & 228 & 200 & 223 & 11 & 17 & 0.057 & $<0.001$ & 0.022 \\
\hline
\end{tabular}

${ }^{1}$ Values are least squares means for each diet ( $n=24$ and $n=20$ for food intake and activity data, respectively) and for dogs of CG and the SG in Ph.I and $\mathrm{Ph} . \mathrm{II}(n=12$ and $n=10$ for food intake and activity level, respectively).

${ }^{2} \mathrm{HC}=$ high-carbohydrate; $\mathrm{HF}=$ high-fat.

${ }^{3} \mathrm{CG}=$ control group; $\mathrm{SG}=$ sterilization group; Ph.I = phase I; Ph.II = phase II. Sterilization effect was assessed as the difference from Ph.I to Ph.II in dogs of the CG that remained intact in both phases vs. dogs of the SG that were spayed in Ph.II (group $\times$ phase interaction).

${ }^{4} \mathrm{SE}$ of the difference (SED) for comparisons between diets and between phases.

${ }^{5} \mathrm{SED}$ for comparisons between phases within $\mathrm{CG}$ and $\mathrm{SG}$.

${ }^{6}$ The interaction diet $\times$ group $\times$ phase was not significant $(P>0.10)$ for any of the parameters.

${ }^{7} \mathrm{ChFI}=$ challenge food intake.

and increased $(P<0.001)$ from Ph.I to Ph.II, with the increase being lower in SG dogs than in CG dogs (group $\times$ phase, $P<0.05$ ).

\section{Basal Concentration of Blood Satiety Hormones}

The significance of diet and sterilization effects on basal concentration of gut-derived hormones is shown in Table 4. Basal concentration of the studied hormones was not affected by diet $(P>0.10)$. The transition from $\mathrm{Ph}$.I to $\mathrm{Ph}$.II was associated with an increase $(P<0.001)$ of CCK and with a decrease $(P<0.001)$ of PYY levels in the fasted state, although these variations were independent of $\operatorname{dog}$ sterilization (group $\times$ phase, $P>0.10$ ).

\section{Postprandial Changes of Blood Satiety Hormones in Response to Diet}

Active ghrelin concentration decreased $(P<$ 0.001 ) from 15 to 60 min postprandially (Fig. 2A) The nadir was reached at 120 min with the HF diet (24.3\% below the baseline) and at $360 \mathrm{~min}$ with the HC diet (18.9\% below the basal value). Postprandial ghrelin suppression did not differ between diets (diet and diet $\times$ time, $P>0.10$ ) and no differences were found in the $\mathrm{nAUC}_{0-120}$ and $\mathrm{nAUC}_{120-360}(P>0.10$; Table 5). Blood levels of CCK increased $15 \mathrm{~min}$ after feeding onward, with the response differing between dietary treatments (diet and diet $\times$ time, $P<$ 0.05 ), with the HF diet leading to a lower and retarded maximal increase (118\% of basal values at $240 \mathrm{~min}$ ) with respect to the HC diet (208\% of basal values at $120 \mathrm{~min})$. The CCK increase was greater at $120(P<$ $0.01)$ and $240 \mathrm{~min}(P<0.05)$ in HC-fed dogs (Fig.
2B) and so were the $\mathrm{nAUC}_{0-120}(P<0.01)$ and the nAUC $_{120-360}(P<0.05$; Table 5). The increase in PYY after meal onset tended to be greater with the $\mathrm{HC}$ diet than with the HF diet from 120 min onward (diet $\times$ time, $P=0.074$ ), and in HF-fed dogs, the maximal increase of PYY was delayed $(53 \%$ of basal values at $240 \mathrm{~min})$ in relation to HC-fed dogs ( $66 \%$ of basal values at $120 \mathrm{~min}$ ). Dietary differences in postprandial PYY variation were significant at $120 \mathrm{~min}(P<0.05$; Fig. 2C), and the nAUC ${ }_{120-360}$ tended to be greater $(P$ $=0.098$ ) with the $\mathrm{HC}$ diet (Table 5). Although insulin maximal increase was delayed in HF-fed dogs $(97 \%$ of basal values at $360 \mathrm{~min}$ ) in relation to $\mathrm{HC}$-fed dogs (125\% of basal values at $60 \mathrm{~min}$ ), there was not an effect of diet on the postprandial evolution of insulin over $360 \mathrm{~min}$ (diet and diet $\times$ time, $P>0.10$; Fig. $2 \mathrm{D})$ or in the $\mathrm{nAUC}_{0-120}$ and $\mathrm{nAUC}_{120-360}(P>0.10$; Table 5). When the basal concentration was considered, dogs fed the HC diet had a greater $(P<0.001)$ tAUC $_{0-240}$ of CCK, whereas the $\mathrm{tAUC}_{0-240}$ of active ghrelin, PYY, and insulin did not differ between diets $(P>0.10$; Table 5).

\section{Postprandial Changes of Blood Satiety Hormones in Response to Sterilization}

Variations in blood concentration of all measured hormones from fasting to $360 \mathrm{~min}$ after feeding were not affected by sterilization (group $\times$ phase and group $\times$ phase $\times$ time, $P>0.10$; Fig. 3 ), so changes in nAUC $_{0-120}$ and nAUC ${ }_{120-360}$ of active ghrelin, CCK, PYY, and insulin from Ph.I to Ph.II did not differ between dog groups (group $\times$ phase, $P>0.10$; Table 5). Sterilization did not affect the $\mathrm{tAUC}_{0-240}$ of active 
Table 4. Effect of diet and sterilization on basal concentration of blood ghrelin (active), cholecystokinin (CCK), total peptide YY (PYY), and insulin ${ }^{1}$

\begin{tabular}{|c|c|c|c|c|c|c|c|c|c|c|c|}
\hline \multirow[b]{3}{*}{ Item } & \multicolumn{2}{|c|}{$\overline{\text { Diet }^{2}}$} & \multicolumn{4}{|c|}{ Sterilization ${ }^{3}$} & \multirow[b]{3}{*}{$\mathrm{SED}^{4}$} & \multirow[b]{3}{*}{$\mathrm{SED}^{5}$} & \multicolumn{3}{|c|}{$P$-value ${ }^{6}$} \\
\hline & \multirow[b]{2}{*}{$\mathrm{HC}$} & \multirow[b]{2}{*}{$\mathrm{HF}$} & \multicolumn{2}{|c|}{$\mathrm{CG}$} & \multicolumn{2}{|c|}{ SG } & & & & & Group \\
\hline & & & Ph.I & Ph.II & Ph.I & Ph.II & & & Diet & Phase & $\times$ phase \\
\hline Ghrelin, pg/mL & 597 & 550 & 561 & 615 & 533 & 585 & 37 & 52 & 0.215 & 0.163 & 0.974 \\
\hline $\mathrm{CCK}, \mathrm{p} M$ & 0.31 & 0.28 & 0.17 & 0.36 & 0.16 & 0.50 & 0.05 & 0.07 & 0.546 & $<0.001$ & 0.146 \\
\hline PYY, pg/mL & 608 & 584 & 804 & 525 & 625 & 431 & 61 & 85 & 0.691 & $<0.001$ & 0.483 \\
\hline Insulin, microunits/mL & 17.9 & 19.5 & 22.0 & 17.6 & 17.8 & 17.4 & 1.8 & 2.4 & 0.379 & 0.170 & 0.249 \\
\hline
\end{tabular}

${ }^{1}$ Values are least squares means for each diet $(n=24)$ and for dogs of the CG and the SG in Ph.I and Ph.II $(n=12)$.

${ }^{2} \mathrm{HC}=$ high-carbohydrate; $\mathrm{HF}=$ high-fat.

${ }^{3} \mathrm{CG}$ = control group; $\mathrm{SG}$ = sterilization group; $\mathrm{Ph} . \mathrm{I}=$ phase I; Ph.II = phase II. Sterilization effect was assessed as the difference from Ph.I to Ph.II in dogs of the CG that remained intact in both phases vs. dogs of the SG that were spayed in Ph.II (group $\times$ phase interaction).

${ }^{4} \mathrm{SE}$ of the difference (SED) for comparisons between diets and between phases.

${ }^{5} \mathrm{SES}$ for comparisons between phases within $\mathrm{CG}$ and $\mathrm{SG}$.

${ }^{6}$ The interaction diet $\times$ group $\times$ phase was not significant $(P>0.10)$ for any of the parameters.

ghrelin, CCK, PYY, and insulin (group $\times$ phase, $P>$ 0.10 ; Table 5).

\section{Correlation between Challenge Food Intake and Blood Satiety Hormones}

There was a negative correlation $(P<0.05)$ between ChFI and the $\mathrm{nAUC}_{0-240}$ and $\mathrm{tAUC}_{0-240}$ of insulin $(r=$ -0.353 and $r=-0.364$, respectively) and a positive correlation between $\mathrm{ChFI}$ and the absolute concentration of active ghrelin at $240 \mathrm{~min}$ after feeding the experimental diets $(r=0.357, P<0.05)$.

\section{DISCUSSION}

There is evidence that diets rich in protein and fiber improve satiety in dogs (Weber et al., 2007). In the present study, we aimed to evaluate the effect of feeding diets differing in the percentage of ME provided by fat or by nonstructural carbohydrates (namely as starch) but with the same percentage of ME provided as protein. Both diets were also formulated with a high level of fiber, similar to that conventionally used in diets designed for weight loss in dogs. The ME content was higher in the HF diet compared with the HC diet (16.9 vs. 14.1 MJ/ $\mathrm{kg}$ DM, respectively) due to its higher fat content and its higher apparent digestibility of fat and protein compared with the HC diet. These ME values were close to those estimated from the chemical composition of the diets using the NRC (2006) approach (16.9 vs. $14.8 \mathrm{MJ} /$ $\mathrm{kg} \mathrm{DM}$ ), which were actually used to establish the level of food offered. Therefore, energy restriction applied to dogs approximated the proposed 0.7 MER.

\section{Effect of the Dietary Fat and Carbohydrate Content on Appetite Control}

The greater DMI and ME intake of the HF diet when offered ad libitum is in line with Warwick (2003), who reported a linear dose response relationship between dietary fat and daily energy intake in rats. The greater DMI of the HF diet could be related to a higher motivation of dogs for diets containing a high fat:carbohydrate ratio. Preference for this macronutrient profile has been previously reported in dogs (Hewson-Hughes et al., 2013) and highlights a predominance of a hedonic-based mechanism of food intake control beyond an energybased one (Erlanson-Albertsson, 2005). However, both diets induced a similar satiety response, as evidenced by the similar intake of the challenge food offered $4 \mathrm{~h}$ after the intake of the experimental diets at 0.7 MER. Previous studies have evidenced a major suppression of intake of a meal offered at 60 and 120 min after a low-fat compared with a high-fat isocaloric preload in rats (Gaysinskaya et al., 2007). Similarly, Blundell et al. (1993) showed in humans that breakfast supplementation with carbohydrates suppressed appetite $90 \mathrm{~min}$ later, whereas isocaloric supplementation with fat did not affect subsequent appetite. However, carbohydrate supplementation had no effect on the intake of a test meal given after $270 \mathrm{~min}$ (Blundell et al., 1993). Also, van der Klaauw et al. (2013) found no differences in the intake of a test meal offered 245 min after feeding a high-fat or a high-carbohydrate breakfast in humans. Therefore, it is possible that the major satiating capacity of carbohydrates may be predominately evidenced soon after food intake instead of several hours after feeding. Furthermore, Geoghegan et al. (1997) found even a major satiating capacity of fat $120 \mathrm{~min}$ after direct infusion of oleate and of a dextrose polymer into the small intestine. In addition, the 30\% energy restriction applied to dogs in the current study during the challenge satiety 


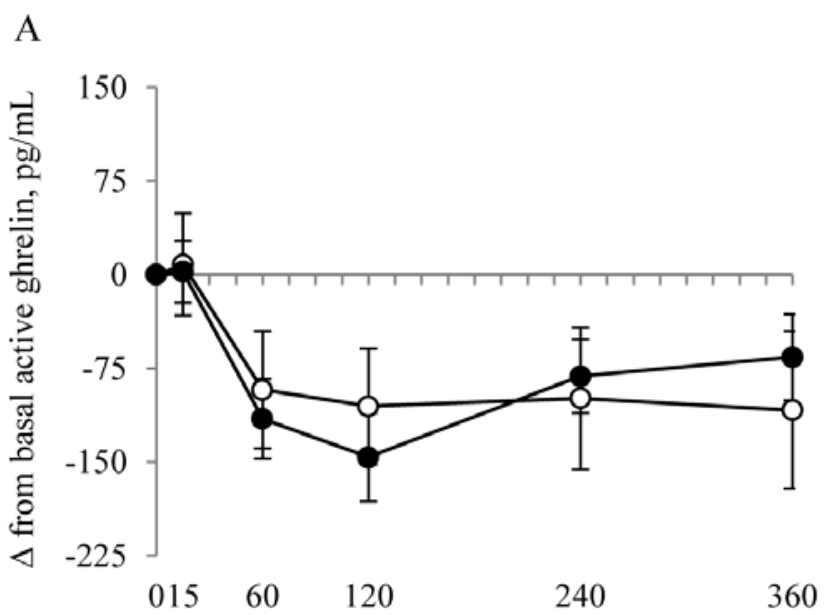

Time after feeding, min

C

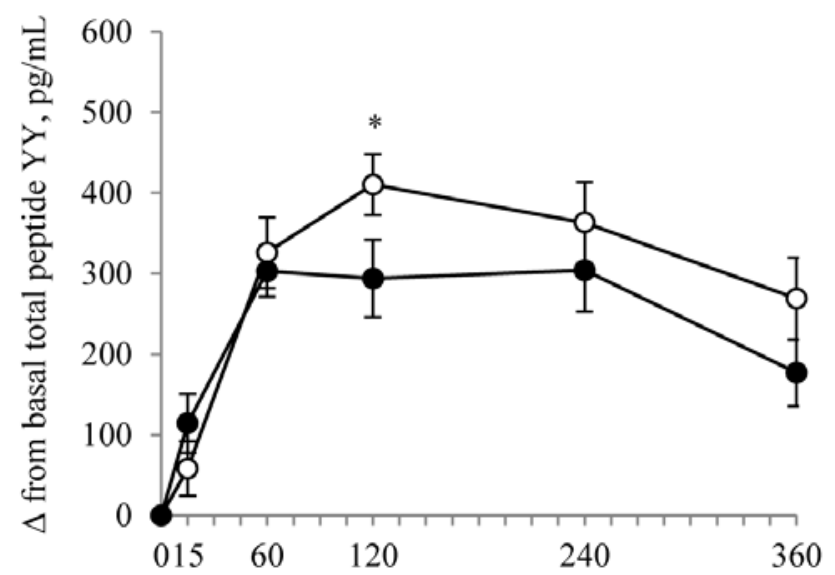

Time after feeding, min
$\mathrm{B}$

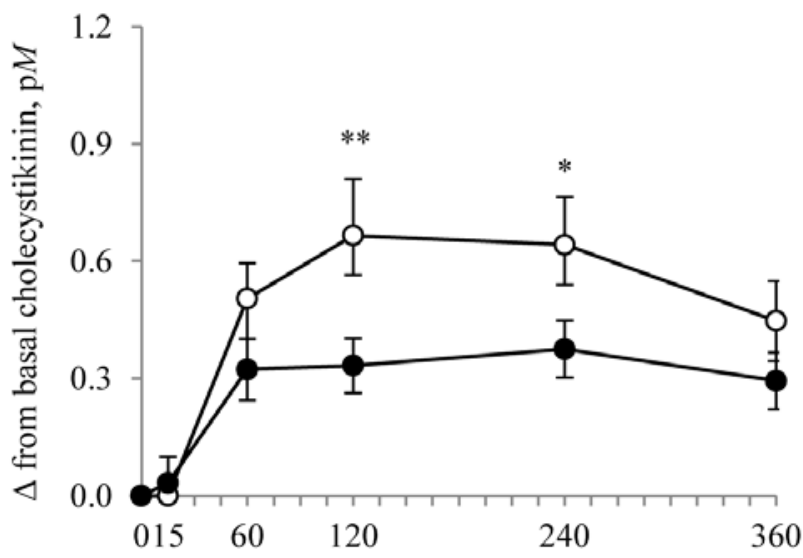

Time after feeding, min

D

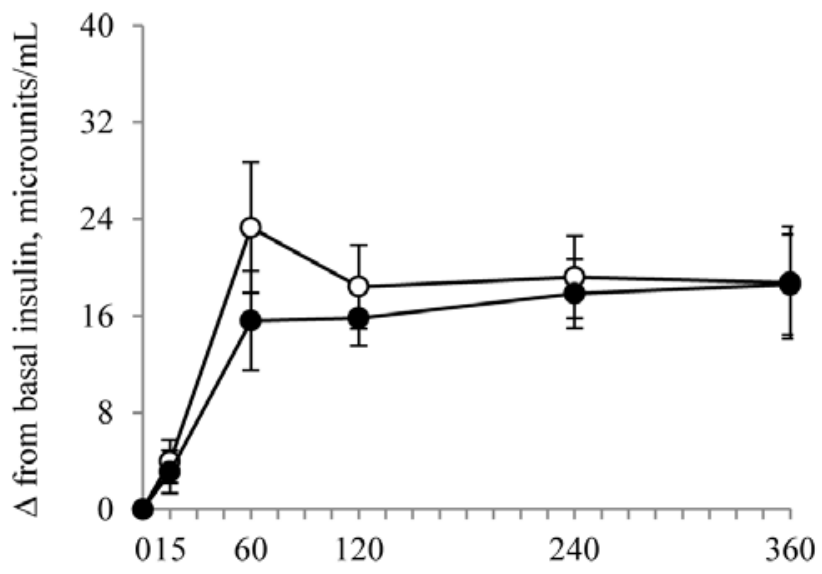

Time after feeding, min

Figure 2. Postprandial variation of active ghrelin (A), cholecystokinin (B), total peptide YY (C), and insulin (D) from basal concentration in dogs fed the high-carbohydrate (-०-) or the high-fat (-๑-) diet. Values are least squares means for $n=24$ dogs per diet, with the SEM represented by vertical bars. Diet effect at each time point, $* P<0.05, * * P<0.01$.

tests could have also affected the feeding response. Thus, in the study of Butterwick and Markwell (1997), dogs fed a low- or a high-fiber diet at 0.4 MER showed no differences in the intake of a common food offered 180 min later, whereas in the study of Bosch et al. (2009) dogs fed a high-fermentable fiber diet at 1 MER showed a trend toward a lower intake of a common food offered $360 \mathrm{~min}$ later in relation to dogs fed a low-fermentable fiber diet.

The activity values obtained in this study are similar to those reported by Hansen et al. (2007) using a similar device in healthy dogs. Interestingly, ad libitum feeding of the HF diet resulted in a reduction in dogs' activity level, which was probably the consequence of their higher level of intake (1.70-fold MER) in comparison with those offered the $\mathrm{HC}$ diet (1.22-fold MER).
Blood concentration of gut-derived hormones did not differ between diets in the fasted state and, as expected, food intake resulted in a suppression of active ghrelin and an increase of CCK, PYY, and insulin levels (Hameed et al., 2009). The similar ghrelin suppression found in HC- and HF-fed dogs is consistent with the study of Lubbs et al. (2010) in dogs, in which no differences between a load of fat and a load of maltodextrin were detected, and with 2 recent studies in humans comparing 2 isocaloric high-carbohydrate and high-fat meals (Gibbons et al., 2013; van der Klaauw et al., 2013), although it differs from previous ones reporting a higher suppression after high-carbohydrate diets (Monteleone et al., 2003; Yang et al., 2009). However, the lower postprandial increase of CCK and PYY found in dogs fed the HF diet contrasts with earlier studies reporting a higher elevation of CCK 
Table 5. Effect of diet and sterilization on net and total area under the curve of blood ghrelin (active), cholecystokinin (CCK), total peptide YY (PYY), and insulin ${ }^{1}$

\begin{tabular}{|c|c|c|c|c|c|c|c|c|c|c|c|}
\hline \multirow[b]{3}{*}{ Item $^{2}$} & \multicolumn{2}{|c|}{$\operatorname{Diet}^{3}$} & \multicolumn{4}{|c|}{ Sterilization $^{4}$} & \multirow[b]{3}{*}{$\mathrm{SED}^{5}$} & \multirow[b]{3}{*}{ SED $^{6}$} & \multicolumn{3}{|c|}{$P$-value ${ }^{7}$} \\
\hline & \multirow[b]{2}{*}{$\mathrm{HC}$} & \multirow[b]{2}{*}{$\mathrm{HF}$} & \multicolumn{2}{|c|}{$\mathrm{CG}$} & \multicolumn{2}{|c|}{ SG } & & & \multirow[b]{2}{*}{ Diet } & \multirow[b]{2}{*}{ Phase } & \multirow{2}{*}{$\begin{array}{l}\text { Group } \\
\times \text { phase }\end{array}$} \\
\hline & & & Ph.I & $\mathrm{Ph} . I I$ & $\mathrm{Ph} . \mathrm{I}$ & Ph.II & & & & & \\
\hline \multicolumn{12}{|l|}{$\mathrm{nAUC}_{0-120}$} \\
\hline Ghrelin, pg/mL & -71.4 & -83.2 & -95.0 & -75.3 & -51.0 & -88.0 & 32.6 & 45.5 & 0.720 & 0.792 & 0.384 \\
\hline $\mathrm{CCK}, \mathrm{p} M$ & 0.41 & 0.22 & 0.38 & 0.46 & 0.18 & 0.23 & 0.07 & 0.09 & 0.009 & 0.307 & 0.829 \\
\hline PYY, pg/mL & 266 & 229 & 223 & 232 & 279 & 256 & 37 & 51 & 0.314 & 0.284 & 0.669 \\
\hline Insulin, microunits/mL & 16.1 & 11.2 & 15.3 & 14.2 & 15.0 & 10.1 & 3.9 & 5.5 & 0.227 & 0.453 & 0.625 \\
\hline \multicolumn{12}{|l|}{$\mathrm{nAUC}_{120-360}$} \\
\hline Ghrelin, pg/mL & -105 & -98.8 & -112 & -123 & -62.8 & -109 & 32.7 & 46.0 & 0.875 & 0.384 & 0.580 \\
\hline $\mathrm{CCK}, \mathrm{p} M$ & 0.59 & 0.34 & 0.73 & 0.57 & 0.27 & 0.29 & 0.09 & 0.13 & 0.010 & 0.417 & 0.332 \\
\hline PYY, pg/mL & 364 & 253 & 279 & 320 & 235 & 400 & 66 & 92 & 0.098 & 0.129 & 0.353 \\
\hline Insulin, microunits/mL & 19.1 & 17.1 & 20.2 & 16.9 & 21.3 & 13.9 & 3.4 & 4.7 & 0.562 & 0.122 & 0.549 \\
\hline \multicolumn{12}{|l|}{ tAUC $_{0-240}$} \\
\hline Ghrelin, pg/mL & 388 & 346 & 344 & 377 & 355 & 378 & 26 & 37 & 0.127 & 0.189 & 0.619 \\
\hline $\mathrm{CCK}, \mathrm{p} M$ & 0.83 & 0.58 & 0.76 & 0.92 & 0.38 & 0.75 & 0.07 & 0.10 & $<0.001$ & $<0.001$ & 0.112 \\
\hline PYY, pg/mL & 937 & 845 & 1,059 & 886 & 870 & 748 & 54 & 76 & 0.103 & 0.013 & 0.641 \\
\hline Insulin, microunits/mL & 35.5 & 32.5 & 38.0 & 35.3 & 34.5 & 28.1 & 3.2 & 4.4 & 0.363 & 0.150 & 0.553 \\
\hline \multicolumn{12}{|c|}{$\begin{array}{l}{ }^{2} \mathrm{nAUC}_{0-120}=\text { net area under the curve from } 0 \text { to } 120 \mathrm{~min} ; \mathrm{nAUC}_{120-360}=\text { net area under the curve from } 120 \text { to } 360 \mathrm{~min} \text {; tAUC } 0-240=\text { total area under } \\
\text { the curve from } 0 \text { to } 240 \mathrm{~min} \text {. } \\
{ }^{3} \mathrm{HC}=\text { high-carbohydrate; } \mathrm{HF}=\text { high-fat. }\end{array}$} \\
\hline \multicolumn{12}{|c|}{$\begin{array}{l}{ }^{3} \mathrm{HC}=\text { high-carbohydrate; } \mathrm{HF}=\text { high-fat. } \\
{ }^{4} \mathrm{CG}=\text { control group; } \mathrm{SG}=\text { sterilization group; } \mathrm{Ph} . \mathrm{I}=\text { phase I; Ph.II = phase II. Sterilization effect was assessed as the difference from Ph.I to Ph.II in } \\
\text { ogs of the CG that remained intact in both phases vs. dogs of the SG that were spayed in Ph.II (group } \times \text { phase interaction). }\end{array}$} \\
\hline
\end{tabular}

in humans fed liquid diets containing corn oil as an individual nutrient with respect to glucose (Liddle et al., 1985) and of PYY in subjects fed a high-fat breakfast compared with subjects fed a high-carbohydrate breakfast (Gibbons et al., 2013). Greeley et al. (1989) also reported a higher PYY rise in dogs after an intraduodenal infusion of oleate compared with an intraduodenal infusion of AA, protein, or glucose. It is possible that the higher DM supply of the HC $\operatorname{diet}$ (to compensate its lower ME content) along with a comparatively faster gastric emptying rate in relation to dogs fed the HF diet (Mizuta et al., 1990) could have contributed to the higher CCK and PYY response of HC-fed dogs. In this respect, Juvonen et al. (2009) reported a major increase of blood CCK and PYY in subjects given a low-viscosity drink promoting a faster gastric emptying than a high-viscosity one. On the other hand, the presence of certain dietary fibers in the experimental diets, such as guar gum and cellulose, may have decreased lipase activity (Schneeman and Gallaher, 1980), which has been found to be key in the elevation of blood CCK (Feinle et al., 2003) and PYY (Degen et al., 2007). Furthermore, in the study of Degen et al. (2007), intraduodenal infusion of a CCK receptor antagonist also abolished PYY secretion in response to intraduodenal fat infusion.

\section{Effect of Dog Sterilization on Appetite Control}

There is strong evidence that dogs gain weight following sterilization (Robertson, 2003; McGreevy et al., 2005). Although this aspect was not the main focus of this work, we found scarce BW changes in spayed dogs and in control dogs during Ph. II ( 1.0 and $-0.5 \% \mathrm{BW}$, respectively), likely because of the $30 \%$ energy restriction applied in different stages of the study. In line with the results obtained by Fettman et al. (1997) in cats, the apparent digestibility of nutrients was not affected by sterilization. Voluntary DMI, measured in the 5th (Period 1, Ph.II) and 11th week (Period 2, Ph.II) after sterilization, and ChFI, measured in the 8th (Period 1, Ph.II) and 14th week (Period 2, Ph.II), were not affected, in contrast to other studies in which energy intake increased after sterilization (Houpt et al., 1979; Jeusette et al., 2004). Discrepancies between experiments might be partly related to differences in the experimental design. For instance, in the study of Jeusette et al. (2004), the effect of sterilization was evaluated before and 6 mo after sterilization in the same group of dogs, although without us- 
A

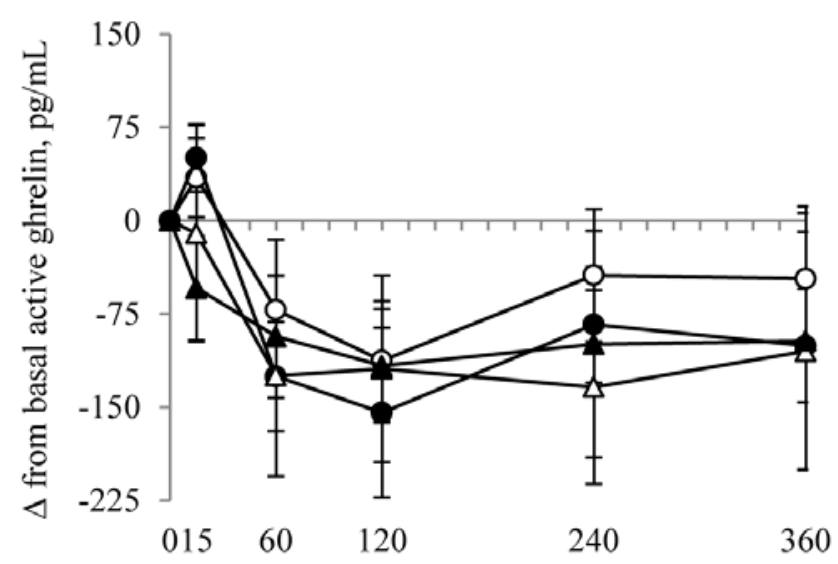

Time after feeding, min

C

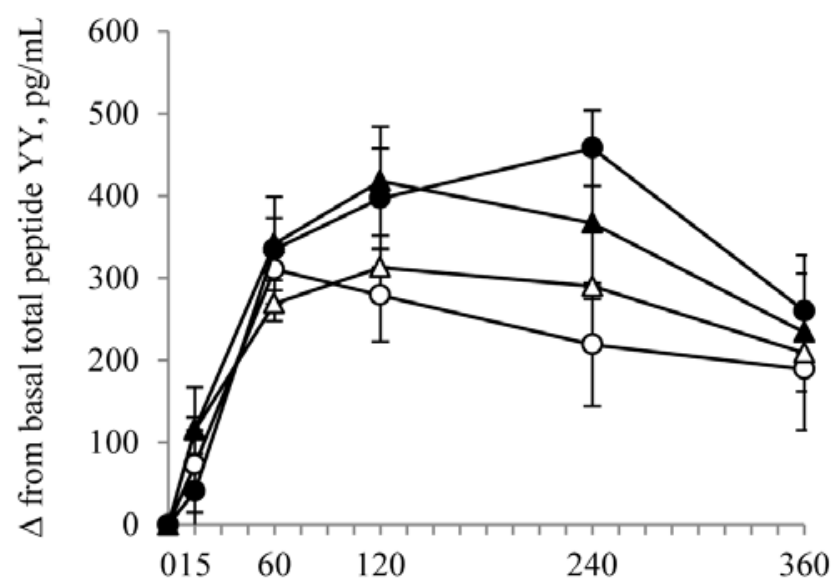

Time after feeding, min
B

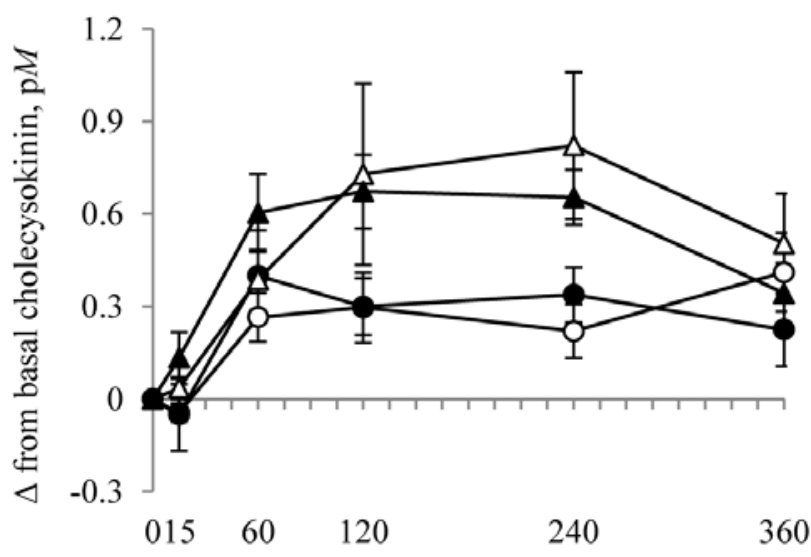

Time after feeding, min

D

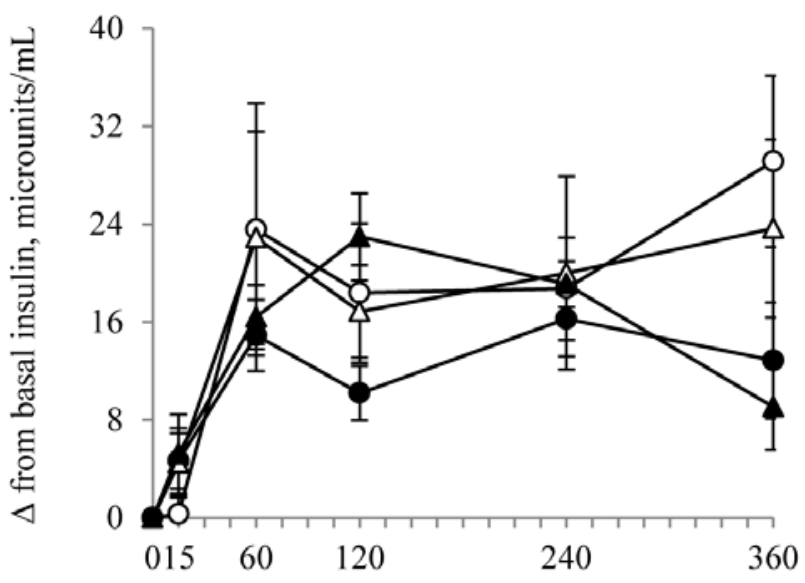

Time after feeding, min

Figure 3. Postprandial variation of active ghrelin (A), cholecystokinin (B), total peptide YY (C), and insulin (D) from basal concentration in dogs of the sterilization group before sterilization (phase I; -०-) and after sterilization (phase II; - $\bullet-$ ) and in dogs of the control group, which were intact in both phases (phase I; $-\Delta$-) and (phase II; - $\mathbf{\Delta}$-). Values are least squares means for $n=12$ data per animal group in each phase, with the SEM represented by vertical bars. Sterilization effect (group $\times$ phase interaction) at each time point, $P>0.10$.

ing a control group. Concerning the study of Houpt et al. (1979), in which a control group of sham operated dogs was included, spayed dogs showed a significant increase of food intake in the second week after sterilization, although not from the third to the fifth week or from the 13th to the 15th week after surgery. Interestingly enough, in this last study, the authors observed a lower daily energy intake in intact dogs during estrus in comparison with diestrus, being highest in anestrus, which indicates that the effect of the reproductive status on food intake control is chiefly related to the cyclic effect of estradiol rather than on a tonic or sustained one. Therefore, considering the reproductive physiology of the female dog in which the stage of estrus has a relatively short duration within the estrous cycle (Feldman and Nelson, 2004), it is arguable whether the lack of estradiol phasic effect in spayed dogs may cause a relevant impairment in food intake control, unlike cats or rats, which share a polyestrous sexual cycle. On this issue, according to a survey conducted by Heidenberger and Unshelm (1990) using a large database of keepers of spayed dogs, only $32 \%$ of these dogs showed changes in feeding behavior toward an increased food intake. There was a phase-related increase in ChFI and activity level in all dogs, irrespective of sterilization, most likely related to the decrease of external temperature from Ph.I to Ph.II $(31 \pm 2.6$ and $15 \pm$ $3.1^{\circ} \mathrm{C}$, respectively), which corroborates the importance of including a control group in these kinds of studies. However, dogs that underwent sterilization did not significantly vary their activity level, unlike control dogs that increased their level of activity in Ph.II. In this regard, the survey of Heidenberger and Unshelm (1990) revealed a 
decrease of activity in $18 \%$ of spayed dogs. Based on our findings, we cannot assert that the increased risk of BW gain occurring in dogs after sterilization is motivated by an increased level of energy intake but possibly by a decreased energy requirement, as reported by Jeusette et al. (2004), derived in part from a decreased physical activity.

Dog sterilization did not affect blood levels of gut-derived hormones in either the fasted or the postprandial state. As a matter of fact, most studies report an effect of estradiol on modulating the satiating and orexigenic effect of gut hormones rather than causing variations in their blood levels (Butera, 2010).

Within the studied hormones, only the postprandial levels of active ghrelin and insulin correlated with the feeding response $4 \mathrm{~h}$ after a meal. Indeed, insulin is a well-established satiety hormone (Schwartz et al., 1992), and a significant correlation between blood ghrelin and food intake previously has been found in humans (Gibbons et al., 2013). By contrast, blood levels of CCK and PYY were not correlated with the feeding response. At this respect, the satiating action of these 2 hormones at physiological levels is not consistently established (Reidelberger et al., 1989; Gibbons et al., 2013).

In conclusion, ad libitum feeding of a high-fat diet led to an increased daily energy intake, suggesting a predominance of a hedonic regulation of food intake over an energy-based one, and tended to reduce the activity level of dogs in comparison with a high-carboydrate diet. When dogs were offered a common diet $4 \mathrm{~h}$ postprandiallly, both diets induced a similar feeding response, reflecting a comparable short-term satiating capacity. Blood levels of CCK and PYY were influenced by the dietary fat and carbohydrate content, showing a higher increase in dogs fed a high-carbohydrate diet, but these changes were not related to changes in food intake $4 \mathrm{~h}$ after feeding. By contrast, blood levels of active ghrelin and insulin correlated with food intake but did not differ between diets. Dog sterilization was not associated with an impaired food intake control or with variations in blood gut-derived hormones from 5 to $15 \mathrm{wk}$ after neutering but mainly with a decreased activity level in relation to sexually intact dogs.

\section{LITERATURE CITED}

AOAC. 1995. Official methods of analysis. 16th ed. AOAC Int., Washington, DC.

AOAC. 2005. Official methods of analysis. 18th ed. AOAC Int., Gaithersburg, MD.

Association of American Feed Control Officials (AAFCO). 2011. Official publication. AAFCO Incorporated, Oxford, IN.

Blundell, J. E., V. J. Burley, J. R. Cotton, and C. L. Lawton. 1993. Dietary fat and the control of energy intake: Evaluating the effects of fat on meal size and postmeal satiety. Am. J. Clin. Nutr. 57:772S-777S.
Bosch, G., A. Verbrugghe, M. Hesta, J. J. Holst, A. F. van der Poel, G. P. J. Janssens, and W. H. Hendriks. 2009. The effects of dietary fibre type on satiety-related hormones and voluntary food intake in dogs. Br. J. Nutr. 102:318-325. doi:10.1017/ S0007114508149194

Butera, P. C. 2010. Estradiol and the control of food intake. Physiol. Behav. 99:175-180. doi:10.1016/j.physbeh.2009.06.010

Butera, P. C., D. M. Bradway, and N. J. Cataldo. 1993. Modulation of the satiety effect of cholecystokinin by estradiol. Physiol. Behav. 53:1235-1238. doi:10.1016/0031-9384(93)90387-U

Butterwick, R. F., and P. J. Markwell. 1997. Effect of amount and type of dietary fiber on food intake in energy-restricted dogs. Am. J. Vet. Res. 58:272-276.

Clegg, D. J., L. M. Brown, J. M. Zigman, C. J. Kemp, A. D. Strader, S. C. Benoit, S. C. Woods, M. Mangiaracina, and N. Geary. 2007. Estradiol-dependent decrease in the orexigenic potency of ghrelin in female rats. Diabetes 56:1051-1058. doi:10.2337/db06-0015

Degen, L., J. Drewe, F. Piccoli, K. Gräni, S. Oesch, R. Bunea, M. D'Amato, and C. Beglinger. 2007. Effect of CCK-1 receptor blockade on ghrelin and PYY secretion in men. Am. J. Physiol. Regul. Integr. Comp. Physiol. 292:R1391-R1399. doi:10.1152/ ajpregu.00734.2006

Erlanson-Albertsson, C. 2005. How palatable food disrupts appetite regulation. Basic Clin. Pharmacol. Toxicol. 97:61-73. doi:10.1111/j.1742-7843.2005.pto_179.x

Feinle, C., D. O’Donovan, S. Doran, J. M. Andrews, J. Wishart, I. Chapman, and M. Horowitz. 2003. Effects of fat digestion on appetite, APD motility, and gut hormones in response to duodenal fat infusion in humans. Am. J. Physiol. Gastrointest. Liver Physiol. 284:G798-G807. doi:10.1152/ajpgi.00512.2002

Feldman, E. C., and R. W. Nelson. 2004. Ovarian cycle and vaginal citology. In: R. Kersey and D. Le Melledo, editors, Canine and feline endocrinology and reproduction. W. B. Saunders, St. Louis, MO.

Fettman, M. J., C. A. Stanton, L. L. Banks, D. W. Hamar, D. E. Johnson, R. L. Hegstad, and S. Johnston. 1997. Effects of neutering on bodyweight, metabolic rate and glucose tolerance of domestic cats. Res. Vet. Sci. 62:131-136. doi:10.1016/S0034-5288(97)90134-X

Gaysinskaya, V. A., O. Karatayev, G. Q. Chang, and S. F. Leibowitz. 2007. Increased caloric intake after a high-fat preload: Relation to circulating triglycerides and orexigenic peptides. Physiol. Behav. 91:142-153. doi:10.1016/j.physbeh.2007.02.002

Geoghegan, J. G., C. A. Cheng, C. Lawson, and T. N. Pappas. 1997. The effect of caloric load and nutrient composition on induction of small intestinal satiety in dogs. Physiol. Behav. 62:39-42. doi:10.1016/S0031-9384(97)00107-8

German, A. J., S. L. Holden, T. Bissot, P. J. Morris, and V. Biourge. 2009. Use of starting condition score to estimate changes in body weight and composition during weight loss in obese dogs. Res. Vet. Sci. 87:249-254. doi:10.1016/j.rvsc.2009.02.007

Gibbons, C., P. Caudwell, G. Finlayson, D. L. Webb, P. M. Hellstrom, E. Naslund, and J. E. Blundell. 2013. Comparison of postprandial profiles of ghrelin, active GLP-1, and total PYY to meals varying in fat and carbohydrate and their association with hunger and the phases of satiety. J. Clin. Endocrinol. Metab. 98:E847E855. doi:10.1210/jc.2012-3835

Greeley, G. H., Jr., T. Hashimoto, M. Izukura, G. Gomez, J. Jeng, F. L. Hill, F. Lluis, and J. C. Thompson. 1989. A comparison of intraduodenally and intracolonically administered nutrients on the release of peptide-YY in the dog. Endocrinology 125:1761-1765. doi:10.1210/endo-125-4-1761

Hameed, S., W. S. Dhillo, and S. R. Bloom. 2009. Gut hormones and appetite control. Oral Dis. 15:18-26. doi:10.1111/j.16010825.2008.01492.x 
Hansen, B. D., B. D. Lascelles, B. W. Keene, A. K. Adams, and A. E. Thomson. 2007. Evaluation of an accelerometer for at-home monitoring of spontaneous activity in dogs. Am. J. Vet. Res. 68:468-475. doi:10.2460/ajvr.68.5.468

Heidenberger, E., and J. Unshelm. 1990. [Changes in the behavior of dogs after castration]. (In German.) Tierarztl. Prax. 18:69-75.

Hewson-Hughes, A. K., V. L. Hewson-Hughes, A. Colyer, A. T. Miller, S. J. McGrane, S. R. Hall, R. F. Butterwick, S. J. Simpson, and D. Raubenheimer. 2013. Geometric analysis of macronutrient selection in breeds of the domestic dog, Canis lupus familiaris. Behav. Ecol. 24:293-304. doi:10.1093/beheco/ars168

Houpt, K. A., B. Coren, H. F. Hintz, and J. E. Hilderbrant. 1979. Effect of sex and reproductive status on sucrose preference, food intake, and body weight of dogs. J. Am. Vet. Med. Assoc. 174:1083-1085.

Jeusette, I., J. Detilleux, C. Cuvelier, L. Istasse, and M. Diez. 2004 Ad libitum feeding following ovariectomy in female Beagle dogs: Effect on maintenance energy requirement and on blood metabolites. J. Anim. Physiol. Anim. Nutr. (Berl.) 88:117-121. doi:10.1111/j.1439-0396.2003.00467.x

Juvonen, K. R., A. K. Purhonen, M. Salmenkallio-Marttila, L. Lahteenmaki, D. E. Laaksonen, K. H. Herzig, M. I. Uusitupa, K. S. Poutanen, and L. J. Karhunen. 2009. Viscosity of oat branenriched beverages influences gastrointestinal hormonal responses in healthy humans. J. Nutr. 139:461-466. doi:10.3945/ jn.108.099945

Karhunen, L. J., K. R. Juvonen, A. Huotari, A. K. Purhonen, and K. H. Herzig. 2008. Effect of protein, fat, carbohydrate and fibre on gastrointestinal peptide release in humans. Regul. Pept. 149:70 78. doi:10.1016/j.regpep.2007.10.008

Laflamme, D. 1997. Development and validation of a body condition score system for dogs. Canine Pract. 22:10-15.

Lawton, C. L., V. J. Burley, J. K. Wales, and J. E. Blundell. 1993. Dietary fat and appetite control in obese subjects: Weak effects on satiation and satiety. Int. J. Obes. Relat. Metab. Disord. 17:409-416.

Liddle, R. A., I. D. Goldfine, M. S. Rosen, R. A. Taplitz, and J. A. Williams. 1985. Cholecystokinin bioactivity in human plasma. Molecular forms, responses to feeding, and relationship to gallbladder contraction. J. Clin. Invest. 75:1144-1152. doi:10.1172/ JCI111809

Lubbs, D. C., B. M. Vester Boler, T. K. Ridge, J. K. Spears, T. K. Graves, and K. S. Swanson. 2010. Dietary macronutrients and feeding frequency affect fasting and postprandial concentrations of hormones involved in appetite regulation in adult dogs. J. Anim. Sci. 88:3945-3953. doi:10.2527/jas.2010-2938

McGreevy, P. D., P. C. Thomson, C. Pride, A. Fawcett, T. Grassi, and B. Jones. 2005. Prevalence of obesity in dogs examined by Australian veterinary practices and the risk factors involved. Vet. Rec. 156:695-702. doi:10.1136/vr.156.22.695
Mizuta, H., Y. Kawazoe, K. Haga, and K. Ogawa. 1990. Effects of meals on gastric emptying and small intestinal transit times of a suspension in the beagle dog assessed using acetaminophen and salicylazosulfapyridine as markers. Chem. Pharm. Bull. (Tokyo) 38:2224-2227. doi:10.1248/cpb.38.2224

Monteleone, P., R. Bencivenga, N. Longobardi, C. Serritella, and M. Maj. 2003. Differential responses of circulating ghrelin to high-fat or high-carbohydrate meal in healthy women. J. Clin. Endocrinol. Metab. 88:5510-5514. doi:10.1210/jc.2003-030797

NRC. 2006. Nutrient requirements of dogs and cats. Natl. Acad. Press, Washington, DC

Papadimitriou, M. A., A. A. Krzemien, P. M. Hahn, and D. A. Van Vugt. 2007. Peptide YY(3-36)-induced inhibition of food intake in female monkeys. Brain Res. 1175:60-65. doi:10.1016/j. brainres.2007.08.001

Rehfeld, J. F. 1998. Accurate measurement of cholecystokinin in plasma. Clin. Chem. 44:991-1001.

Reidelberger, R. D., T. J. Kalogeris, and T. E. Solomon. 1989. Plasma CCK levels after food intake and infusion of CCK analogues that inhibit feeding in dogs. Am. J. Physiol. 256:R1148-R1154.

Robertson, I. D. 2003. The association of exercise, diet and other factors with owner-perceived obesity in privately owned dogs from metropolitan Perth, WA. Prev. Vet. Med. 58:75-83. doi:10.1016/ S0167-5877(03)00009-6

Schneeman, B. O., and D. Gallaher. 1980. Changes in small intestinal digestive enzyme activity and bile acids with dietary cellulose in rats. J. Nutr. 110:584-590.

Schwartz, M. W., D. P. Figlewicz, D. G. Baskin, S. C. Woods, and D. Porte Jr. 1992. Insulin in the brain: A hormonal regulator of energy balance. Endocr. Rev. 13:387-414.

van der Klaauw, A. A., J. M. Keogh, E. Henning, V. M. Trowse, W. S. Dhillo, M. A. Ghatei, and I. S. Farooqi. 2013. High protein intake stimulates postprandial GLP1 and PYY release. Obesity (Silver Spring) 21:1602-1607. doi:10.1002/oby.20154

Warwick, Z. S. 2003. Dietary fat dose dependently increases spontaneous caloric intake in rat. Obes. Res. 11:859-864. doi:10.1038/ oby. 2003.118

Weber, M., T. Bissot, E. Servet, R. Sergheraert, V. Biourge, and A. J. German. 2007. A high-protein, high-fiber diet designed for weight loss improves satiety in dogs. J. Vet. Intern. Med. 21:1203-1208. doi:10.1111/j.1939-1676.2007.tb01939.x

Yang, N., X. Liu, E. L. Ding, M. Xu, S. Wu, L. Liu, X. Sun, and F. B. Hu. 2009. Impaired ghrelin response after high-fat meals is associated with decreased satiety in obese and lean Chinese young adults. J. Nutr. 139:1286-1291. doi:10.3945/jn.109.104406

Zietlow, A., H. Nakajima, H. Taniguchi, K. Ludwig, and T. Takahashi. 2010. Association between plasma ghrelin and motilin levels during MMC cycle in conscious dogs. Regul. Pept. 164:78-82. doi:10.1016/j.regpep.2010.05.006 